\title{
US drops Imanishi-Kari investigation; Baltimore withdraws Cell retraction
}

Washington. US prosecutors announced this week that they are dropping their criminal investigation of Thereza Imanishi-Kari, a Tufts University immunologist accused of scientific misconduct, because the case is too complex and tangled for a jury to reach a conclusion. At the same time, David Baltimore, a Nobel prizewinner and co-author with Imanishi-Kari of the questioned work, which appeared in Cell in 1986, said that he would withdraw a retraction made last year after the second of two investigations by the National Institutes of Health (NIH) found evidence of misconduct. Although the government action is a victory for ImanishiKari, the saga, which has lasted six years and become the centrepiece for debate over research ethics, is expected to continue.

Baltimore resigned last year from the presidency of Rockefeller University after being dogged by criticism of his conduct during the extended investigation. He says that his retraction was made on the basis of statistical and forensic studies commissioned by NIH that appeared to prove that ImanishiKari had fabricated data.

But an independent analysis commissioned earlier this year by Imanishi-Kari's attorney, Bruce Singal of the Boston law firm Ferriter, Scobbo, Sikora, Caruso \& Rodophele, concluded that the forensic analysis by the US Secret Service was seriously flawed. The reanalysis, by Albert Lyter, a former US Treasury forensic chemist, concluded that the Secret Service analysis suffered from "inadequate samples of data, erroneous interpretations of test results ... and poor methodology and procedures."

Singal says that all he and Imanishi-Kari needed was a chance to see the data. "We've been crying in the wilderness for years, trying to get the data [on which the Secret Service based its conclusions]", he says. "Finally we got a responsible party in the form of the US attorney, who allowed us to see the data."

Baltimore says there "has been no contradiction and extensive confirmation" of the Cell paper, including replication of the central experiment by Imanishi-Kari herself. "I now believe that there is no reason for the paper to be in limbo", he says. The new forensic analysis "is a confirmation of my feeling all along that Imanishi-Kari had not attempted to deceive anybody".

However, Geoffrey Garinther, an assistant US attorney in Baltimore, Maryland, says that the reanalysis of the forensic evidence did not cause his office to end its 18month investigation. "Our decision was not based on a lack of confidence in the Secret Service findings," he says. Instead, he says that prosecutors felt that the controversy was essentially a scientific one and that a conviction would be extremely difficult.

"We couldn't take this to the jury and ask them to decide it when there are so many scientists who disagree", he says. If ImanishiKari's lawyers "could suggest to the jury that she'd done the experiments or that her results had been verified by others, that's enough for reasonable doubt", he says.

Phillip Sharp, a Massachusetts Institute of Technology researcher who has championed Baltimore's case, says that Baltimore had never wanted to retract the paper, and jumped at the first opportunity to reverse his decision. Sharp says that the retraction in March 1991 had been "under the pressure of being president of Rockefeller and wanting to put the whole thing behind him".

In a letter dated 13 July to the oversight and investigations subcommittee of the Energy and Commerce Committee, chaired by US Representative John Dingell (Democrat, Michigan), Richard Bennett, the US attorney for Maryland, pointed out that the statistical evidence upon which NIH had relied would be inadmissible in a criminal trial. And he predicted that the Secret Service's forensic analysis would have been contradicted by the independent analysis commissioned by Singal. "We are confident that the [Secret Service] testimony would have been persuasive," he wrote. "Our duty, however, is not simply to persuade, but to persuade beyond a reasonable doubt."

A grand jury had already heard from witnesses when prosecutors decided not to seek an indictment in the case. The jurors "were clearly incapable of understanding" the case, says one scientist who testified before the grand jury and who did not wish to be identified. "They literally pulled 24 people off the street."

Dingell said that "the decision not to prosecute does not change the fact that the Cell paper was retracted because of serious, and extensive, irregularities". He said that the US attorneys had told his subcommittee that they agreed with the Secret Service finding of falsification of data "but believe that the matter was too complicated for a lay jury".

Suzanne Hadley, the former NIH investigator who wrote the report that found evidence of misconduct, criticized the decision to drop criminal prosecution. "If [Imanishi-Kari] did falsify data, or lie to federal investigators, those were federal crimes and they should be dealt with in the criminal sector", she says. The NIH investigation is continuing, although Hadley was removed from her position after clashing with NIH officials over her impartiality.

Imanishi-Kari described the six-year inquiry as a "terrible injustice". Now that she no longer faces the threat of criminal prosecution, she says she will ask NIH to release a 1989 grant that had been frozen during the investigation. In the wake of the decision, she says, "I feel that, after all that, there is some justice. I was doubting before."

Christopher Anderson \& Traci Watson

\section{Audit faults US national labs}

Washington. As if the misuse of federal research funds by prominent universities was not bad enough, the US government now believes that some of its own laboratories have been playing fast and loose with federal money. Last week, the US Senate released a report accusing some of the government's 39 research centres of inadequate accounting, careless auditing and poor cost control. Such practices, it says, have "contributed to the wasteful or inappropriate use of millions of federal dollars".

The report by an oversight committee of the Senate Committee on Government Affairs says that poor record-keeping prevents it from knowing how much money has been misspent. The Lawrence Livermore, Los Alamos and Lawrence Berkeley national laboratories - all operated by the University of California for the Department of Energy (DOE) - are the most frequently mentioned in the report.

The report deals with some of the same management issues that are being investigated by Congress as part of an inquiry into how universities bill the government for the overhead cost of conducting research. That investigation has uncovered millions of dollars in improper charges.

Among the most egregious examples of the University of California's behaviour are the following: From 1988 to 1991, the DOE reimbursed the university for the cost of leasing 58 vehicles for the Livermore site, although the department had ordered Livermore to reduce the size of its fleet. And the university continued to collect lease money even after the DOE bought the vehicles and gave them to the university. Tommy Ambrose, who manages UC's office of laboratory affairs, agrees that "we didn't manage that situation well".
Traci Watson 